\title{
Pengelompokan Kabupaten/Kota di Provinsi Aceh Dengan Metode Ward Berdasarkan Indikator Derajat Kesehatan Masyarakat
}

\author{
Wahyudi \\ Sekolah Tinggi Agama Islam Negeri Gajah Putih Takengon, Aceh Tengah \\ Jl. Yos Sudarso/A Dimot No. 10 Takengon, Telp (0643) 23268 \\ Email: yudiwahyu204@gmail.com
}

\begin{abstract}
ABSTRAK
Derajat kesehatan merupakan salah satu ukuran kesejahteraan dan kualitas sumber daya manusia di suatu wilayah. Perbedaan kondisi kesehatan antar wilayah menyebabkan adanya kesulitan yang dihadapi pemerintah dalam mengambil kebijakan pembangunan di bidang kesehatan. Analisis pengelompokan sering digunakan untuk mengalisis kesamaan karakteristik antar wilayah. Penelitian ini bertujuan untuk mengelompokkan kabupaten/kota di Provinsi Aceh berdasarkan indikator derajat kesehatan masyarakat. Data yang digunakan merupakan data sekunder yang diperoleh dari badan pusat statistik (BPS) dan dinas kesehatan provinsi Aceh yang kemudian dianalisis dengan menggunakan metode pengelompokan Ward. Hasil penggerombolan kabupaten/kota di provinsi Aceh dengan metode Ward terbagi kedalam 3 gerombol. Gerombol satu terdiri dari 4 kabupaten/kota, gerombol dua terdiri dari 5 kabupaten/kota yang kesemuanya merupakan daerah kabupaten dan gerombol tiga terdiri dari 14 kabupaten/kota yang dimana 4 diantaranya merupakan daerah perkotaan.
\end{abstract}

Kata Kunci: Derajat Kesehatan, Gerombol, Metode Ward.

\begin{abstract}
Health degree is a measure of the welfare and quality of human resources in an area. Differences in health conditions between regions cause diffculties faced by the government in taking development policies in the health sector. Cluster analysis is often used to analyze the similarity of characteristics between regions. This research aims to cluster regencies/cities in Aceh Province based on indicators of the degree of public health. The data used are secondary data obtained from BPS and the Aceh provincial health office which are than analyzed using the Ward clustering method. The result of the clustering of regencies/cities in Aceh province by the Ward method were divided into 3 groups. Group 1 consists of 4 regencies/cities, group 2 consist of 5 regencies/cities which are all regency areas and group 3 consists of 14 regencies/cities of which 4 them are urban areas.
\end{abstract}

Keywords:

Keywords: Health Degree, Cluster, Ward Method

\section{Pendahuluan}

Derajat kesehatan merupakan salah satu ukuran kesejahteraan dan kualitas sumber daya manusia (SDM). SDM yang sehat merupakan modal utama dalam pelaksanaan pembangunan suatu daerah. Salah satu ciri daerah yang maju adalah mempunyai derajat kesehatan yang tinggi, karena mempunyai pengaruh sangat besar terhadap kualitas sumber daya manusianya. Terbitnya Peraturan Bersama Menteri Dalam Negeri dan Menteri Kesehatan Nomor 34 Tahun 2005 dan Nomor 
1138/Menkes/PB/VIII/2005 tentang Penyelenggaraan Kabupaten/Kota Sehat menuntut setiap provinsi di Indonesia untuk melahirkan Kabupaten/Kota yang Sehat. Berdasarkan data dari kementerian kesehatan tahun 2016 Provinsi Aceh termasuk kedalam lima besar provinsi yang memiliki Kabupaten/Kota sehat terendah secara nasional. Hal ini dikarenakan kondisi derajat kesehatan masyarakat di Aceh yang heterogen sehingga menyulitkan bagi Tim Pembina Kabupaten/Kota Sehat dalam melakukan pembinaan dan monitoring. Oleh karena itu, penggerombolan kabupaten/kota di provinsi Aceh perlu dilakukan agar terlihat kelompok kabupaten/kota yang belum memiliki derajat kesehatan masyarakat dan pelayanan kesehatan yang memadai. Hal ini dilakukan dengan cara membagi kabupaten/kota menjadi beberapa kelompok dimana kabupaten/kota pada kelompok yang sama memiliki kemiripan yang tinggi dibandingkan dengan kabupaten/kota pada kelompok yang berbeda.

Upaya untuk melakukan penggerombolan suatu objek sering dilakukan dengan analisis cluster (analisis gerombol). Salah satu metode penggerombolan dalam analisis gerombol adalah metode Ward. Johnson \& Wichern [5] menyatakan bahwa metode Ward menggabungkan gerombol dengan meminimalkan hilangnya informasi data dengan menggunakan kriteria error sum of square. Selanjutnya Wahyudi et al, [7] menyebutkan bahwa metode Ward merupakan metode yang paling baik dalam menggerombolkan objek untuk segala kondisi karena selalu konsisten memberikan persentase ketepatan penggerombolan yang tinggi. Pada penelitian ini penggerombolan kabupaten/kota di provinsi Aceh akan dilakukan menggunakan metode Ward. Adapun tujuan dilakukannya penelitian ini adalah untuk menggerombolkan kabupaten/kota di Provinsi Aceh berdasarkan indikator derajat kesehatan masyarakat menggunakan metode penggerombolan Ward.

\section{Metode dan Bahan Penelitian}

\section{Sumber Data}

Data yang digunakan dalam penelitian ini adalah data profil kesehatan Aceh dan merupakan data sekunder yang diperoleh dari Dinas Kesehatan Provinsi Aceh Tahun 2016 serta Badan Pusat Statistik (BPS) Provinsi Aceh tahun 2016. Objek yang digunakan dalam penelitian ini adalah 23 Kabupaten/Kota yang berada di Wilayah Provinsi Aceh. Data pada penelitian ini diolah menggunakan package software R. Adapun indikator derajat kesehatan masyarakat yang digunakan sebagai peubah untuk melakukan penggerombolan Kabupaten/Kota dapat dilihat pada Tabel 1.

Tabel 1 Daftar peubah penggerombolan kabupaten/kota di provinsi Aceh

\begin{tabular}{lcl}
\hline Indikator & Peubah & Keterangan \\
\hline Mortalitas & $X_{1}$ & Angka kematian balita \\
& $X_{2}$ & Angka kematian bayi \\
& $X_{3}$ & Angka kematian ibu \\
\hline Morbiditas & $X_{4}$ & Jumlah penderita penyakit HIV/AIDS \\
\hline
\end{tabular}




\begin{tabular}{lcl}
\hline & $X_{5}$ & Jumlah penderita penyakit IMS \\
$X_{6}$ & Jumlah penderita penyakit DBD \\
$X_{7}$ & Jumlah penderita penyakit Diare \\
$X_{8}$ & Jumlah penderita penyakit TB \\
\hline Status Gizi & $X_{9}$ & Jumlah bayi mengalami gizi buruk
\end{tabular}

Peubah yang dipilih menggunakan termonologi dari Kementerian Kesehatan Republik Indonesia (2016)

\section{Metode Analisis}

Langkah-langkah analisis data pada penelitian ini dilakukan dengan mengacu pada Everitt et al [4] sebagai berikut :

1. Melakukan eksplorasi data secara deskriptif

2. Menghitung korelasi antar peubah

3. Melakukan transformasi pada data dengan prosedur analisis faktor untuk menghilangkan korelasi yang ada antar peubah

4. Melakukan penggerombolan dengan metode Ward dengan angkah-langkah sebagai berikut:

a. Menghitung jarak setiap objek menggunakan jarak Euclidean.

b. Menghitung nilai error sum of square (ESS) untuk setiap objek yang tergabung dengan rumus :

$$
E S S=\sum_{i=1}^{N}\left(x_{i}-\bar{x}\right)^{T}\left(x_{i}-\bar{x}\right)
$$

dengan :

$$
\begin{aligned}
\text { ESS } & =\text { nilai dari error sum of square } \\
x_{i} & =\text { vektor objek ke- } i \\
\bar{x} & =\text { vektor rataan gerombol } \\
N & =\text { banyaknya objek dalam suatu gerombol }
\end{aligned}
$$

c. Menggabungkan objek dengan memilih nilai ESS yang terkecil.

d. Menghitung ulang nilai ESS untuk gerombol yang terbentuk.

e. Ulangi langkah d sampai semua objek tergabung menjadi satu gerombol besar.

5. Melakukan interpretasi dan membuat kesimpulan hasil penggerombolan

\section{Hasil dan Pembahasan}




\section{Eksplorasi Data}

Eksplorasi data dilakukan untuk mengetahui sebaran nilai dari setiap indikator derajat kesehatan masyarakat seperti rata-rata, ragam, korelasi, dan pencilan. Deskripsi gambaran umum terkait data disajikan sebagai berikut :

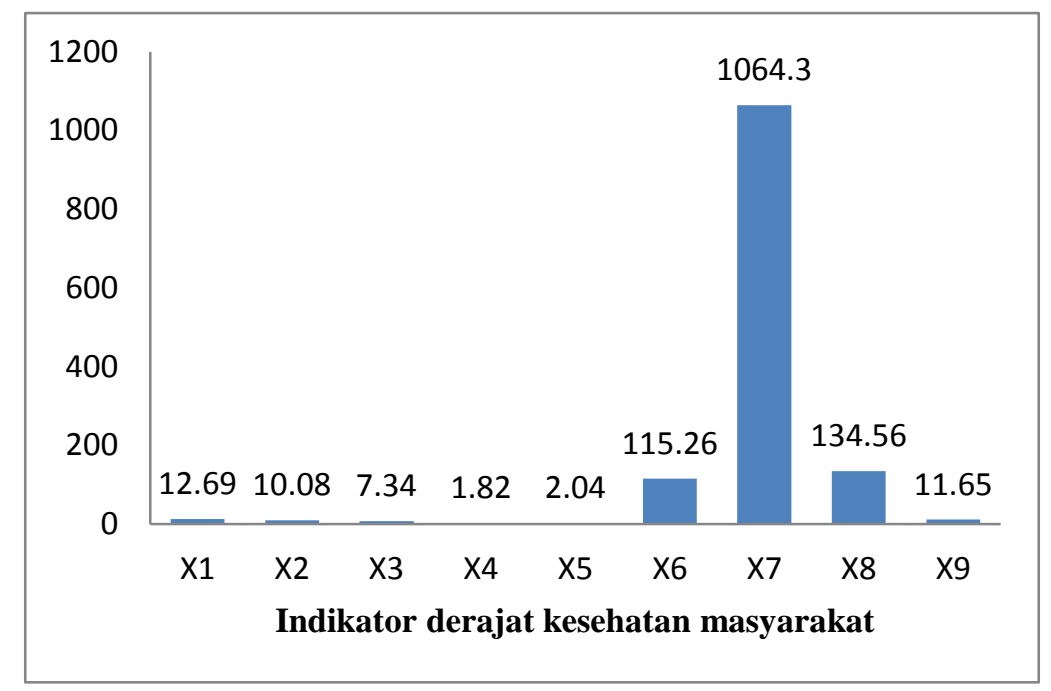

Gambar 1. Nilai rata-rata setiap peubah indikator derajat kesehatan masyarakat

Beberapa peubah memiliki perbedaan nilai rata-rata yang cukup jauh. Peubah-peubah pada angka pesakitan (morbiditas) menunjukkan bahwa rata-rata jumlah penderita penyakit merupakan yang dominan tinggi jika dibandingkan dengan peubah yang lain. Hal ini mengindikasikan bahwa rendahnya kesadaran masyarakat akan perilaku hidup sehat. Jumlah penderita penyakit Diare $\left(X_{7}\right)$ merupakan peubah dengan nilai rata-rata penderita penyakit tertinggi sebesar 1064,30. Selain itu, angka kematian balita $\left(X_{l}\right)$ dan jumlah bayi mengalami gizi buruk $\left(X_{9}\right)$ menunjukkan nilai rata-rata yang cukup tinggi yaitu berturut-turut sebesar 12,69 dan 11,65. Hal ini memberikan informasi bahwa masih belum baiknya pembangunan di bidang kesehatan.

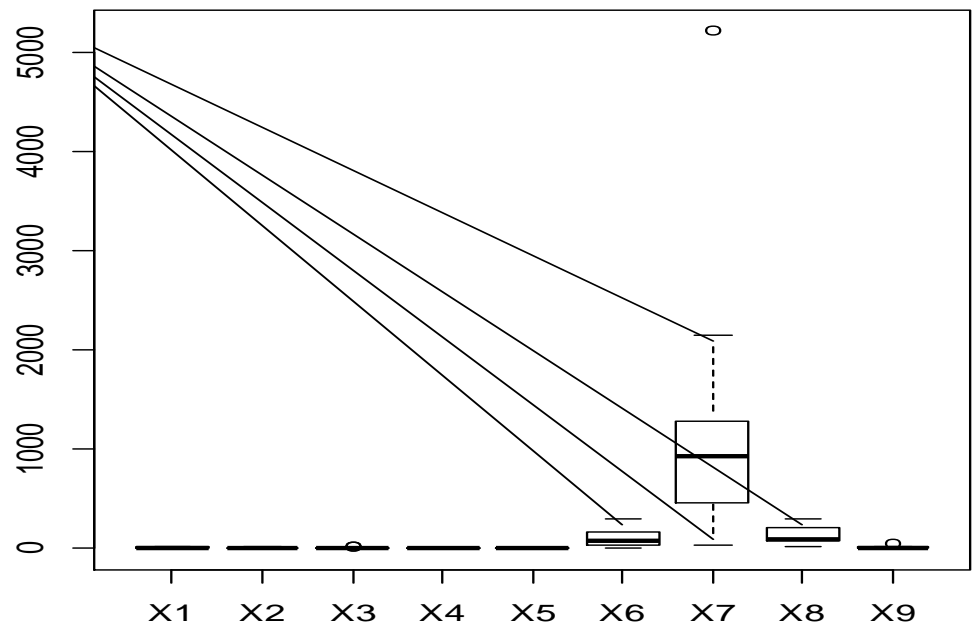

Gambar 2. Boxplot peubah indikator derajat kesehatan masyarakat 
Boxplot memperlihatkan bahwa peubah $X_{6}, X_{7}$, dan $X_{8}$ merupakan peubah dengan ragam yang cukup besar. Sedangkan peubah lainnya memiliki ragam yang kecil. Peubah $X_{7}$ merupakan peubah dengan ragam terbesar dan peubah dengan ragam terkecil yaitu $X_{4}$. Selain itu terdapat data pencilan untuk beberapa peubah yaitu peubah $X_{3}, X_{7}$, dan $X_{9}$.

Tabel 2 Nilai korelasi antar peubah penggerombolan

\begin{tabular}{|c|c|c|c|c|c|c|c|c|c|}
\hline & $X_{l}$ & $X_{2}$ & $X_{3}$ & $X_{4}$ & $X_{5}$ & $X_{6}$ & $X_{7}$ & $X_{8}$ & $X_{9}$ \\
\hline$X_{I}$ & 1 & & & & & & & & \\
\hline$X_{2}$ & 0.802 & 1 & & & & & & & \\
\hline$X_{3}$ & -0.239 & -0.102 & 1 & & & & & & \\
\hline$X_{4}$ & -0.317 & -0.062 & 0.105 & 1 & & & & & \\
\hline$X_{5}$ & -0.044 & 0.189 & 0.119 & 0.633 & 1 & & & & \\
\hline$X_{6}$ & -0.279 & -0.081 & 0.251 & 0.682 & 0.497 & 1 & & & \\
\hline$X_{7}$ & 0.303 & 0.358 & 0.083 & 0.388 & 0.357 & 0.373 & 1 & & \\
\hline$X_{8}$ & -0.439 & -0.241 & 0.569 & 0.640 & 0.402 & 0.592 & 0.259 & 1 & \\
\hline$X_{9}$ & -0.338 & -0.102 & 0.775 & 0.195 & 0.168 & 0.155 & 0.132 & 0.517 & 1 \\
\hline
\end{tabular}

Nilai korelasi memperlihatkan bahwa adanya keeratan hubungan antar peubah penggerombolan yang digunakan. Nilai korelasi antar peubah sebagian besar memiliki korelasi yang cukup tinggi. Jarak Euclidean mensyaratkan tidak adanya korelasi antar peubah pada data. Oleh sebab itu, dilakukan proses transformasi data dengan analisis faktor untuk mendapatkan nilai antar peubah penggerombolan yang saling bebas lewat nilai skor faktor. Untuk mendapatkan skor faktor yang mempunyai karakteristik paling mirip dengan karakteristik data asal maka digunakan seluruh komponen faktor dalam menggerombolkan kabupaten/kota.

\section{Penggerombolan Kabupaten/Kota}

Kabupaten/kota di wilayah provinsi Aceh berdasarkan indikator derajat kesehatan dengan metode Ward digerombolkan ke dalam 3 gerombol. Penentuan banyaknya gerombol yang terbentuk dilakukan dengan melihat selisih lompatan jarak yang cukup besar pada koefisien penggabungannya. Menurut Everitt [4] struktur gerombol yang terbentuk melalui analisis gerombol selalu lebih stabil untuk selisih lompatan jarak yang jauh. Hasil penggerombolan disajikan dalam Tabel 3 sebagai berikut :

Tabel 3 Hasil penggerombolan kabupaten/kota

\begin{tabular}{ccc}
\hline Gerombol & Banyak anggota gerombol & Nama kabupaten/kota \\
\hline 1 & 4 & Pidie Jaya, Aceh Barat Daya, Sabang, dan Gayo Lues
\end{tabular}




\begin{tabular}{|c|c|c|}
\hline 2 & 5 & $\begin{array}{l}\text { Nagan Raya, Aceh Jaya, Aceh Singkil, Bener Meriah, } \\
\text { dan Simeulue }\end{array}$ \\
\hline 3 & 14 & $\begin{array}{l}\text { Pidie, Bireuen, Aceh Selatan, Aceh Tamiang, Langsa, } \\
\text { Aceh Tengah, Subussalam, Aceh Utara, Aceh Timur, } \\
\text { Aceh Besar, Aceh Barat, Lhokseumawe, Banda Aceh, } \\
\text { dan Aceh Tenggara }\end{array}$ \\
\hline
\end{tabular}

Setiap gerombol yang terbentuk memiliki karakteristik yang berbeda-beda namun relatif sama untuk setiap anggota digerombol yang sama. Berikut ini adalah nilai rata-rata peubah penggerombolan untuk setiap gerombol yang terbentuk :

Tabel 4 Deskripsi rata-rata setiap peubah berdasarkan gerombol

\begin{tabular}{lccc}
\hline \multicolumn{1}{c}{ Indikator /Peubah } & Gerombol 1 & Gerombol 2 & Gerombol 3 \\
\hline Mortalitas & $18.60^{\mathrm{a}}$ & 16.00 & 9.64 \\
$X_{1}$ & $17.20^{\mathrm{a}}$ & 6.25 & 8.64 \\
$X_{2}$ & 5.60 & 3.50 & $9.07^{\mathrm{a}}$ \\
$X_{3}$ & & & \\
Morbiditas & 0.40 & 0.25 & $2.79^{\mathrm{a}}$ \\
$X_{4}$ & 0.80 & 0.50 & $2.93^{\mathrm{a}}$ \\
$X_{5}$ & 26.60 & 53.50 & $164.57^{\mathrm{a}}$ \\
$X_{6}$ & 869.20 & 997.25 & $1153.14^{\mathrm{a}}$ \\
$X_{7}$ & 58.40 & 75.25 & $178.71^{\mathrm{a}}$ \\
$X_{8}$ & & & \\
Status gizi $_{X_{9}}$ & & & \\
\hline${ }^{\mathrm{a}}$ rata-rata tertinggi & 7.00 & 3.25 & \\
\hline
\end{tabular}

Gerombol 1 merupakan kelompok kabupaten/kota yang memiliki karakteristik derajat kesehatan masyarakat yang rendah dimana angka kematian (mortalitas) menunjukkan angka yang tinggi yaitu angka kematian balita $\left(X_{1}\right)$ dan kematian bayi $\left(X_{2}\right)$ yang dominan terjadi. Menurut Endra [4] mortalitas dan morbiditas yang meningkat menunjukkan derajat kesehatan masyarakat rendah dan sebaliknya. Gerombol 2 sebagai kelompok kabupaten/kota yang memiliki karakteristik derajat kesehatan masyarakat yang memadai jika dibandingkan dengan gerombol lainnya. Gerombol 3 merupakan kelompok kabupaten/kota yang memiliki karakteristik derajat kesehatan masyarakat yang sangat rendah dikarenakan angka kematian (mortalitas) yaitu angka kematian ibu $\left(X_{3}\right)$, angka pesakitan (morbiditas) yaitu jumlah penderita penyakit HIV/AIDS $\left(X_{4}\right)$, jumlah penderita penyakit IMS $\left(X_{5}\right)$, jumlah penderita penyakit DBD $\left(X_{6}\right)$, jumlah penderita penyakit Diare $\left(X_{7}\right)$, jumlah penderita penyakit TB $\left(X_{8}\right)$, dan status gizi yaitu jumlah bayi mengalami gizi buruk $\left(X_{9}\right)$ yang dominan tinggi. Gerombol 3 sebagai kelompok kabupaten/kota yang perlu mendapatkan 
perhatian lebih dari pemerintah terkait derajat kesehatan masyarakat serta dalam upaya peningkatan kabupaten/kota sehat.

\section{Kesimpulan}

Penggerombolan kabupaten/kota di Provinsi Aceh berdasarkan indikator derajat kesehatan masyarakat menggunakan metode Ward terbagi menjadi 3 gerombol. Gerombol satu terdiri dari 4 kabupaten/kota yang menyebar di provinsi Aceh. Gerombol dua terdiri dari 5 kabupaten/kota yang kesemuanya merupakan daerah kabupaten. Gerombol tiga terdiri dari 14 kabupaten/kota yang 4 diantaranya merupakan daerah perkotaan. Guna meningkatkan kondisi kesehatan masyarakat dan jumlah kabupaten/kota sehat di Provinsi Aceh, maka monitoring, evaluasi dan pengambilan kebijakan dapat dilakukan oleh Pemerintah Provinsi Aceh berdasarkan gerombol yang terbentuk. Selain itu, disarankan untuk penelitian lanjutan untuk menggunakan metode penggerombolan lain yang berkembang saat ini dan melibatkan lebih banyak variabel lain.

\section{Daftar Pustaka}

[1] Badan Pusat Statistika,. Provinsi Aceh dalam Angka 2017. Banda Aceh, Badan Pusat Statistika, 2017.

[2] Dinas Kesehatan Provinsi Aceh,. Profil Kesehatan Aceh Tahun 2016. Banda Aceh, Dinas Kesehatan Provinsi Aceh, 2016

[3] Endra, Febri BS,. Pengantar Ilmu Kesehatan Masyarakat. Malang, Universitas Muhammadiyah Malang, 2008.

[4] Everitt, BS., Landau, S., Leese, M. and Stahl, D., Cluster Analysis $5^{\text {th }}$ edition. The Atrium, Southern Gate, Cichester, West Sussex, PO19 8 Sq : John Willey and Sons Ltd,. 2011

[5] Johnson, RA., \& Wichern, DW,. Applied Multivariate Statistical Analysis (6th Edition). London : Prentice-Hall, 2007

[6] Kementerian Kesehatan Republik Indonesia,. Profil Kesehatan Indonesia tahun 2016. Jakarta, Kementerian Kesehatan Republik Indonesia, 2016.

[7] Wahyudi., Notodiputro, K.A., Kurnia, Anang., \& Annisa, R,. A Study Of Area Clustering Using Factor Analysis In Small Area Estimation (An Analysis Of Per Capita Expenditures Of Subdistricts Level In Regency And Municipality Of Bogor). AIP Conference Proceedings, 1707, 080017; 10.1063/1.4940874, 2016 